\title{
Health information provided by retail health food outlets
}

\author{
Jaclyn Calder $\mathrm{BSc}^{1}$, Robert Issenman MD FRCPC ${ }^{2}$, Ruth Cawdron MA ${ }^{2}$
}

\begin{abstract}
J Calder, R Issenman, R Cawdron. Health information provided by retail health food outlets. Can J Gastroenterol 2000;14(9):767-771. Alternative health practices have become increasingly popular in recent years. Many patients visit specific complementary practitioners, while others attempt to educate themselves, trusting advice from employees at local health food stores or the Internet. Thirty-two retail health food stores were surveyed on the nature of the information provided by their staff. A research assistant visited the stores and presented as the mother of a child in whom Crohn's disease had been diagnosed. Seventytwo per cent ( 23 of 32 ) of store employees offered advice, such as to take nutritional and herbal supplements. Of the 23 stores where recommendations were made, 15 (65\%) based their recommendation on a source of information. Fourteen of the 15 stores using information sources used the same reference book. This had a significant impact on the recommendations; the use of nutritional supplements was favoured.

In conclusion, retail health food stores are not as inconsistent as hypothesized, although there are many variances in the types of supplements recommended for the same chronic disease.
\end{abstract}

Key Words: Alternative medicine; Complementary medicine; Crohn's disease; Retail health food stores

\section{Information sur la santé fournie par les détaillants en aliments de santé}

RÉSUMÉ : La médecine parallèle a gagné beaucoup de popularité au cours des dernières années. Beaucoup de patients se tournent vers la médecine douce, tandis que d'autres tentent de faire leur propre apprentissage en faisant confiance aux conseils donnés par les détaillants en aliments de santé ou dans Internet. Une enquête a été menée auprès de 32 magasins de produits de santé sur la nature de l'information fournie par le personnel. Une adjointe à la recherche s'est fait passer pour la mère d'un enfant souffrant de la maladie de Crohn. Dans 23 magasins sur 32 (72\%), les employés ont donné des conseils, par exemple prendre des suppléments nutritionnels ou des produits à base d'herbes médicinales. Des 23 magasins en question, 15 (65\%) ont fondé leurs recommandations sur une source d'information et 14 d'entre eux ont utilisé le même livre de référence. Cela a eu pour effet de donner une portée importante aux recommandations, et on préconisait le recours aux suppléments nutritionnels. Il ressort de l'enquête que les détaillants en aliments de santé ne sont pas aussi incohérents qu'on pourrait le croire, mais les recommandations quant au type de suppléments à utiliser différaient grandement, et ce, pour le traitement de la même maladie chronique.
A lternative health practices have become increasingly popular. An Internet survey in 1999 indicated that $34 \%$ of a North American inflammatory bowel disease (IBD) population were currently using some form of complementary therapy (1). Other studies have shown similar results, with a general trend toward an increasing use of complementary medicine (2). There are many types of alternative therapies available, including vitamins, nutritional supplements, herbal supplements, traditional Eastern medicine and homeopathy. Many patients visit specific complementary practitioners, while others attempt to educate themselves, trusting advice obtained from local health food stores or the Internet. According to a study done in the United Kingdom, when a subject reported recent onset of repeated headaches, of 29 health food stores, employees at seven $(24 \%)$ suggested seeing a doctor, employees at 27 (93\%) offered specific advice and employees at 21 (72\%) took diagnostic information (3). To our knowledge, no studies examining the advice obtained from health food store employees have been published in North America.

It is not known how this use of alternative therapies affects allopathic medical practices and the interactions be-

${ }^{1}$ University of Guelph, Guelph; ${ }^{2}$ Department of Pediatrics, McMaster University and The Children's Hospital, Hamilton Health Sciences,

Hamilton, Ontario

Correspondence: Dr Robert Issenman, McMaster University, HSC-3F31, 1200 Main Street West, Hamilton, Ontario L8N 325.

Telephone 905-521-2100 ext 75637,fax 905-521-2655, e-mail issenman@fhs.mcmaster.ca

Received for publication September 14, 1999. Accepted January 24, 2000 
TABLE 1

Distribution of health food stores surveyed in the Central West Health Region of Ontario

\begin{tabular}{lc}
\hline City & Number $(\mathbf{n}=\mathbf{3 2})$ \\
\hline Burlington & 11 \\
Cambridge & 2 \\
Guelph & 8 \\
Hamilton & 5 \\
Kitchener & 1 \\
Oakville & 2 \\
St Catharines & 3 \\
\hline
\end{tabular}

tween the two fields. The patient is said to be more active in complementary medicine rather than in conventional medicine (1). Many patients with IBD do not inform their gastroenterologists of their use of complementary medicine (4). The major reason for this lack of communication is that patients view physicians as either intolerant or ignorant in the field of complementary medicine (4). Many physicians have recognized a need to increase their knowledge of this rapidly expanding field (4). By becoming more familiar with the advice offered by health food store employees, physicians might enhance the patient-physician relationship.

It is assumed that most adults have the ability to weigh alternatives and reason before following advice from an unregulated industry. Whether their thinking is rational or not, adults are viewed as being able to make their own health-related decisions. Children, on the other hand, lack this ability and are generally governed by the decisions of their parents or guardians. This creates a potential hazard if the advice from these stores is not safe or is not finely tuned to the patient's age.

The objective of the present research was to study the nature of health information given by staff from a random sample of retail health food stores in the Central West Health Region pertaining to a pediatric patient with a chronic illness.

It was hypothesized that, as an unregulated industry, health food stores might dispense uninformed, inconsistent and commercially motivated health information to consumers. We wondered whether the advice would be inappropriate to the pediatric age of the client, and possibly dangerous and undermining to the conventional medical treatment of a serious chronic disease. A secondary hypothesis was that the health food retail outlets serve as a conduit to treatment by unregulated health counsellors.

\section{SUBJECTS AND METHODS}

The Central West Health Region of Ontario comprises Kitchener/Waterloo, Guelph, Cambridge, Brantford, Hamilton, Burlington, Oakville, St Catharines, Welland, Niagara Falls and the surrounding communities. The population of the region is approximately two million. 'Health food retail' stores were identified using a search engine on the Internet site Yellowpages.ca (5). A sample of these stores was
TABLE 2

Health food stores in the Central West Health Region of Ontario providing a recommendation for the treatment of Crohn's disease

\begin{tabular}{lc}
\hline Recommendation* & $\begin{array}{c}\text { Number (\%) } \\
(\mathbf{n = 2 2 )}\end{array}$ \\
\hline Herbal supplements & $7(32)$ \\
Nutritional supplements & $8(36)$ \\
Both herbal and nutritional supplements & $4(18)$ \\
Other recommendations & $3(14)$ \\
All three (herbal, nutritional and other) & $1(5)$ \\
\hline
\end{tabular}

*More than one recommendation possible

selected using a random number table. A research assistant then visited the stores selected and presented as the young mother of a child in whom Crohn's disease had been diagnosed. The employee was asked whether they could offer any suggestions. If further information was sought, staff were told that the child had the following characteristics:

- six years old;

- taking sulphasalazine;

- seeing a gastrointestinal specialist; and

- taking children's multivitamins.

Stores were visited within eight weeks of each other; the number was determined by the time available for completion of the study.

\section{RESULTS}

Surveys were completed for 32 stores, with a demographic breakdown as indicated (Table 1). Several different types of health food stores were identified. Some stores were individual supplement and vitamin stores, others were part of a grocery store or department store, and some were health food markets selling mostly natural and organic foods (as opposed to supplements). Employees at $72 \%$ (23 of 32) of the stores recommended a treatment for the patient. Employees at nine stores did not make a recommendation; five stated that the stores were health food markets selling health foods and, therefore, did not give advice. Employees at the remaining four stores withheld a recommendation for other reasons, such as inexperienced staff or young age of the child. One store only sold body building supplements.

Of the $72 \%$ of stores ( 23 of 32 ) where advice was offered, the most common recommendations were herbal supplements $(32 \%)$, nutritional supplements $(36 \%)$ or both $(18 \%)$ (Table 2). Herbal supplements were defined as all herbs and herbal blends, and nutritional supplements were defined as all vitamins, food supplements, minerals, fatty acids, etc. There were two referrals to naturopaths, and one offer for instore muscle testing - a method of muscle testing that proponents claim reflects tolerance to foods and herbs.

Of the 23 stores where a recommendation was made, 15 $(65 \%)$ based their recommendation on a published source of information. One store used a computer database, while 14 
TABLE 3

Sources of information used by health food stores in the Central West Health Region of Ontario

\begin{tabular}{lc}
\hline Information source & $\begin{array}{c}\text { Number }(\%) \\
(\mathbf{n = 2 3 )}\end{array}$ \\
\hline Prescription for Nutritional Healing (6) & $14(61)$ \\
In-store computer system & $1(4)$ \\
No source & $8(35)$ \\
\hline
\end{tabular}

TABLE 4

Products recommended for the treatment of Crohn's disease at health food stores in the Central West Health Region of Ontario that used, and those that did not use, Prescription for Nutritional Healing (6) as a reference

\begin{tabular}{|c|c|c|c|c|}
\hline $\begin{array}{l}\text { Supplements } \\
\text { recommended* }\end{array}$ & $\begin{array}{c}\text { Did not use } \\
\text { book }(\%) \\
(n=9)\end{array}$ & $\begin{array}{l}\text { Used book (\%) } \\
\quad(n=14)\end{array}$ & $\begin{array}{c}\text { Total (\%) } \\
(n=23)\end{array}$ & $P(\text { at } 95 \%)^{\dagger}$ \\
\hline \multicolumn{5}{|l|}{ Herbal } \\
\hline No & $4(44 \%)$ & 7 (50\%) & $11(48 \%)$ & \\
\hline Yes & $5(56 \%)$ & $7(50 \%)$ & 12 (52\%) & \\
\hline Total & $9(100 \%)$ & $14(100 \%)$ & 23 (100\%) & 0.795 \\
\hline \multicolumn{5}{|l|}{ Nutritional } \\
\hline No & $6(67 \%)$ & $3(21 \%)$ & 9 (39\%) & \\
\hline Yes & $3(33 \%)$ & 11 (79\%) & $14(61 \%)$ & \\
\hline Total & $9(100 \%)$ & $14(100 \%)$ & $23(100 \%)$ & 0.030 \\
\hline
\end{tabular}

${ }^{*}$ More than one recommendation possible; ${ }^{\dagger}$ These numbers are suspect due to a small population

of 23 (61\%) stores used the same text, Prescription for Nutritional Healing, by Balch and Balch (6) (Table 3). Use of this book resulted in a statistically significant number of stores favouring the use of nutritional, as opposed to herbal, supplements. Employees at $79 \%$ of the stores using Prescription for Nutritional Healing (6) as a reference, and at 33\% of stores not using the book, recommended nutritional supplements. Findings from the stores that gave advice are shown in Table 4.

At $26 \%$ (six of 23 ) of stores where a recommendation was made, further supplementary information was provided. Supplementary information was classified as any changes in dose compared with that given in information sources or by manufacturers, as well as suggestions to call support groups, disease associations or a doctor. A visit with the physician was advised without recommending a specific product at only one store (Table 5).

One-quarter of store employees explicitly stated taking special consideration of the patient's young age, although it is possible that other stores' employees made this consideration without directly stating so. With regard to taking special consideration for age, no difference was observed between those who used the text as a reference and those who did not (Table 6).

There was a high degree of consistency in terms of the reference resource used by stores. However, the advice given was more inconsistent, in that many different herbal and nutritional supplements were recommended (Tables 7, 8).
TABLE 5

Supplementary information provided for a patient with Crohn's disease by employees at health food stores in the Central West Health Region of Ontario

\begin{tabular}{lc}
\hline Supplementary information & Number $(\mathbf{\%})(\mathbf{n = 2 3 )}$ \\
\hline Suggested seeing a doctor & $3(13 \%)$ \\
Gave other supplementary information & $3(13 \%)$ \\
Total & $6(26 \%)$ \\
Did not give any supplementary $\quad$ information & $17(74 \%)$ \\
\hline
\end{tabular}

TABLE 6

Health food store employees in the Central West Health Region of Ontario who considered the age of the patient when giving advice regarding the treatment of Crohn's disease

\begin{tabular}{lc}
\hline Age-related consideration & Number $(\%)(\mathbf{n}=\mathbf{3 2})$ \\
\hline Yes & $8(25 \%)$ \\
No & $24(75 \%)$ \\
\hline
\end{tabular}

TABLE 7

Herbs recommended for the treatment of Crohn's disease by employees of health food stores in the Central West Health Region of Ontario

\begin{tabular}{lc}
\hline Herbs recommended* & Number \\
\hline Herbal blend & 4 \\
Aloe vera juice & 5 \\
Cat's claw & 1 \\
Echinacea & 2 \\
Fenugreek & 1 \\
Red clover & 1 \\
Burdock & 1 \\
Peppermint & 1 \\
Marshmallow & 1 \\
Slippery elm & 1 \\
Wild Indigo & 1 \\
Goldenseal & 1 \\
Cranesbill & 1 \\
Turmeric & 1 \\
Garlic & 1
\end{tabular}

*More than one recommendation possible

\section{DISCUSSION}

This study has shown that employees of retail health food stores are not as inconsistent in their recommendations as was hypothesized. Although there were wide variations in recommendations for a specific disease, most employees (65\% of stores advising) turned to a reference source before making a recommendation when dealing with an unfamiliar disease. The fact that 14 (61\%) stores used the same book was unexpected and shows some consistency among stores. 
TABLE 8 Nutritional supplements recommended for the treatment of
Crohn's disease by employees of health food stores in the
Central West Region of Ontario

\begin{tabular}{lc}
\hline Supplement recommended $^{*}$ & Number \\
\hline Acidophilus & 4 \\
Psyllium & 1 \\
Essential fatty acids $^{\dagger}$ & 7 \\
Multivitamin & 2 \\
Vitamin C $^{+}$ & 2 \\
Vitamin B complex & 5 \\
Folic acid & 1 \\
Vitamin B12 & 1 \\
Iron & 1 \\
Zinc & 2 \\
Vitamin A & 1 \\
Vitamin D & 1 \\
Lipase & 1 \\
Digestive enzymes & 1 \\
Glutamine & 1 \\
\hline
\end{tabular}

${ }^{*}$ More than one recommendation possible; ${ }^{\dagger}$ Omega 3 and 6, flaxseed oil, primrose oil or fish oil (eicosapentanoic acid and/or docosahexanoic acid)

This suggests that a majority of the stores surveyed referred to guidelines when providing recommendations to consumers. The lack of coherence in the choice of supplements for a specific disease (Crohn's disease) is consistent with a description by Griever (7), who indicated that there was very little correlation between a patient's clinical status and the type of therapy chosen. There were a few dominant supplements, which kept surfacing throughout this study, including aloe vera juice, essential fatty acids, vitamin B complex and acidophilus. This lends some credence to the possibility of developing guidelines or authoritative recommendations, even if there are conflicting views further complicated by the immense quantities of different products available. The lack of published, credible research into the efficacy of complementary medical therapies is a further difficulty.

It is very difficult to determine whether the advice given was appropriate to the pediatric age of the client. Employees at six $(27 \%)$ of the 23 stores where advice was given indicated giving special consideration to age, while employees at only four $(13 \%)$ of all 32 stores suggested visiting a doctor. This is consistent with what was found in the study done in the United Kingdom by Vickers et al (3), in which staff at only seven (24\%) stores suggested seeing a doctor when faced with a client describing medical symptoms.

It was hypothesized that the advice obtained at health food stores would be dangerous and would undermine conventional medical treatment. Over the course of the study, no store employee suggested stopping medical treatment or refraining from following the advice of a doctor. In fact, the staff at four $(13 \%)$ of the stores sent the client to visit their doctor. Still, the safety of the supplements recommended is unknown. There are relatively few studies proving the effi- cacy and safety of herbal and nutritional supplements, although studies have proved the efficacy of an enteric-coated fish oil (8); the need for zinc, folic acid, vitamin B12 and iron (9); and the need for vitamin A $(10,11)$ and vitamin D (1214 ) in Crohn's disease. No studies were found to prove the efficacy of glutamine supplements in Crohn's disease; one study found no evidence that it restores intestinal permeability in patients with Crohn's disease (15).

Knowing that the majority of stores use the same source of information is reassuring, provided that the source is credible. The quality of Prescription for Nutritional Healing (6) is arguable from a scientific view. The book seems to start with broadly accepted definitions of disease, diagnosis and treatment, but then adds elements derived from diverse areas of what is termed 'complementary medicine'. Many common practices in alternative medicine do not have studies published in scientific journals due to a lack of scientific rigour and funds; therefore, it is difficult to find substantial supportive information. Unfortunately, Balch and Balch (6) provided an inconsistent distinction between credible information derived through scientific methodology and recommendations derived from unsubstantiated theory or traditional practices. Katz and Weinberg (16) listed supplements that were suggested for the treatment of Crohn's disease in Prescription for Nutritional Healing (6) for which they could not find any scientific basis, including liver extract injections, pancreatin, garlic, L-glutamine, bovine duodenal glandular tissue and taurine plus. They also stated that the popular literature suggests a myriad of untried and perhaps deleterious treatments (16). The use and safety of alternative health foods in this condition remain controversial.

The staff at only two stores referred the patient to specific naturopaths, indicating that the number of stores serving as a conduit to unregulated practitioners is very limited. Although cross-referral does occur, the data indicate that it is a rare event.

In the present study, few conclusions can be made as to the safety of advice given by health food store employees because of the small sample size. Recommendations detrimental to the health of the patient were not given, yet proof of the safety and efficacy of suggestions is unavailable. More information is needed regarding the safety and uses of many herbs and nutritional supplements. Ultimately, the nature of health benefits and risks of herbal products must be determined through systematic study - a daunting task given the huge variety of products and manufacturers. Similarly, some form of surveillance to identify risky products and practices, and a system for disseminating accurate information and alerts to health food stores need to be established. Findings from this exploratory study might form the basis for other more specific studies on advice from health food stores and the effect of specific supplements in Crohn's disease and related diseases.

\section{REFERENCES}

1. Hilsden RJ, Meddings JB, Verhoef MJ. Complementary and

alternative medicine use by patients with inflammatory bowel disease: An Internet survey. Can J Gastroenterol 1999;13:327-32. 
2. Rawsthorne P, Shanahan F, Cronin NC, et al. An international survey of the use and attitudes regarding alternative medicine by patients with inflammatory bowel disease. Am J Gastroenterol 1999;94:1298-303.

3. Vickers AJ, Rees RW, Robin A. Advice given by health food shops: is it clinically safe? J R Coll Physicians Lond 1998;32:426-8.

4. Hilsden RJ, Scott CM, Verhoef MF. Complementary medicine use by patients with inflammatory bowel disease. Am J Gastroenterol 1998;93:697-701.

5. Yellowpages.ca. $<$ http://www.yellowpages.ca $>$. (Version current at September 15, 2000).

6. Balch JF, Balch CL. Prescription for Nutritional Healing. New York: Avery Publishing, 1997.

7. Griever M. The cure is in the bag. JAMA 1998;159:1498.

8. Belluzzi A, Brignola C, Campieri M, Pera A, Boschi S, Migioli M. Effect of an enteric-coated fish-oil preparation on relapses in Crohn's disease. N Engl J Med 1996;334:1557-60.

9. Imes S, Pinchbeck BR, Dinwoodie A, Walker K, Thomson AB. Iron, folate, vitamin B-12, zinc, and copper status in outpatients with Crohn's disease: effect of diet counseling. J Am Diet Assoc 1987;87:928-30.
10. Skough M, Sundquist T, Tagesson C. Vitamin A in Crohn's disease. Lancet 1980;i:766. (Lett)

11. Dvorak AM. Vitamin A in Crohn's disease. Lancet 1980:i:1303-4.

12. Leichtmann GA, Bengoa JM, Bolt MJG, Sitrin MD. Intestinal absorption of cholecalciferol and 25-hydroxycholecalciferol in patients with both Crohn's disease and intestinal resection. Am J Clin Nutr 1991;54:548-52.

13. Harris AD, Brown R, Heatley RV, et al. Vitamin D status in Crohn's disease: association with nutrition and disease activity. Gut 1985;26:1197-203.

14. Driscoll RH, Meredith SC, Sitrin M, Rosenberg IH. Vitamin D deficiency and bone disease inpatients with Crohn's disease. Gastroenterology 1982;83:1252-8.

15. Hond ED, Hiele M, Peeters M, Ghoos Y, Rutgeerts P. Effect of longterm oral glutamine supplements on small intestinal permeability in patients with Crohn's disease. JPEN J Parenter Enteral Nutr 1999;23:7-11.

16. Katz J, Weinberg L. Complementary medicine use by patients with inflammatory bowel disease. Am J Gastroenterol 1998;93:673-5. 


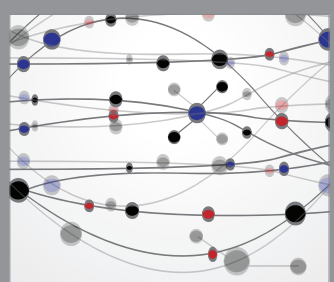

The Scientific World Journal
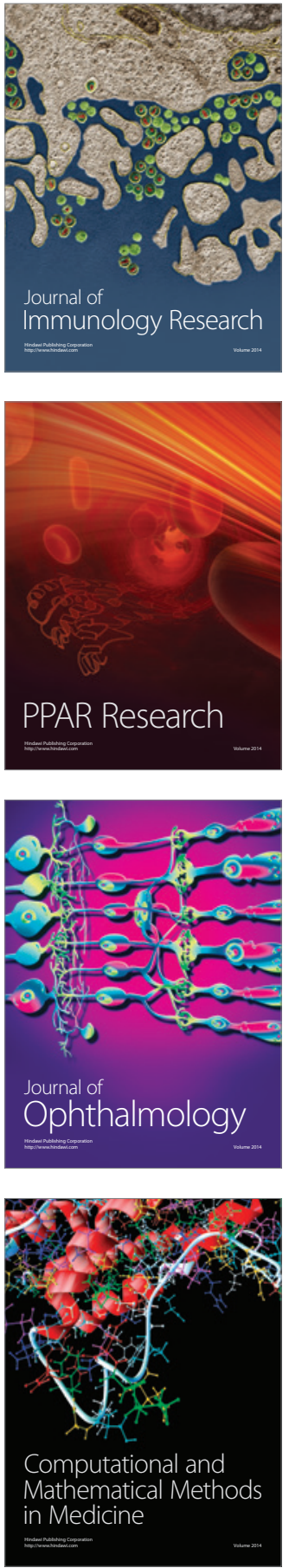

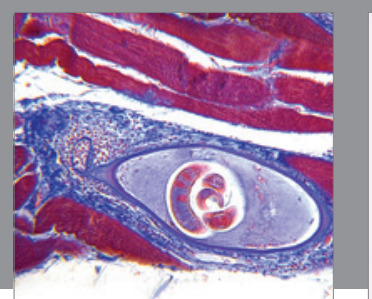

Gastroenterology Research and Practice

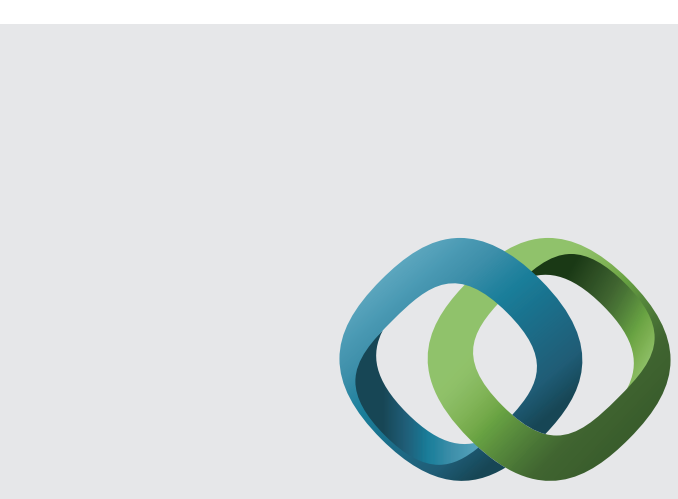

\section{Hindawi}

Submit your manuscripts at

http://www.hindawi.com
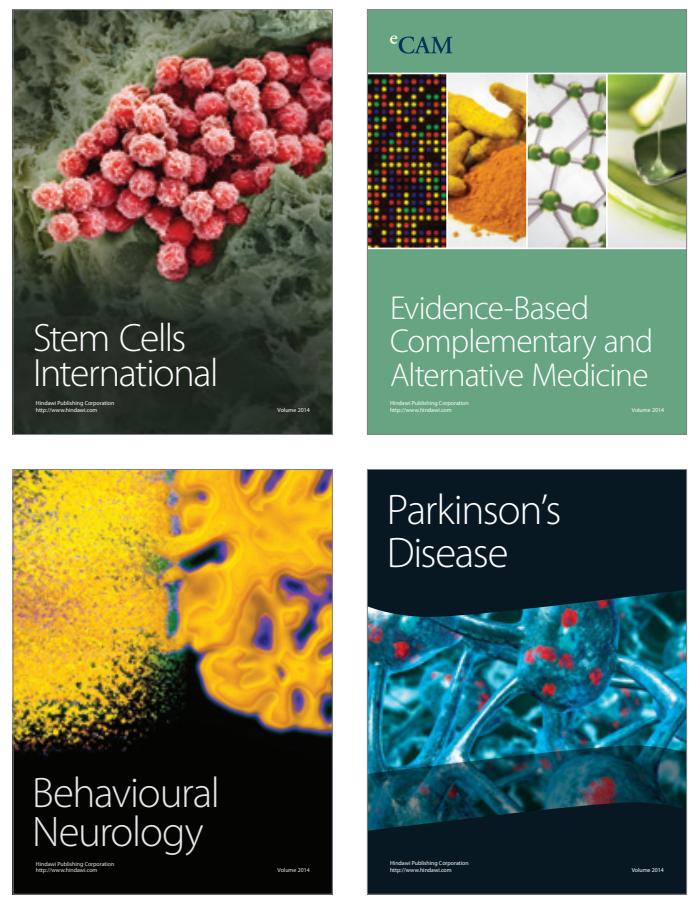
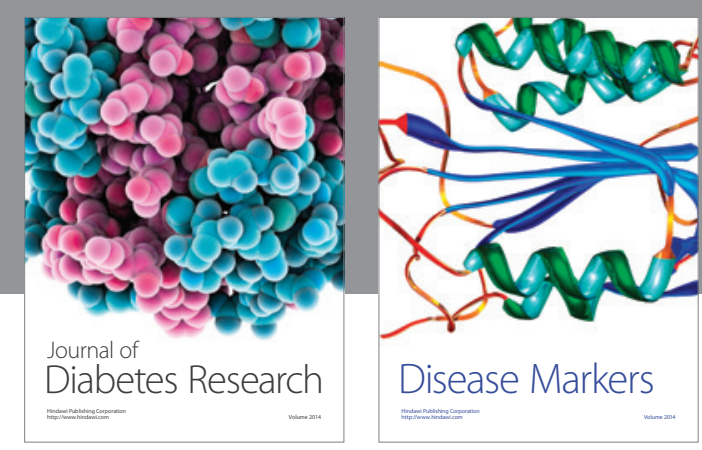

Disease Markers
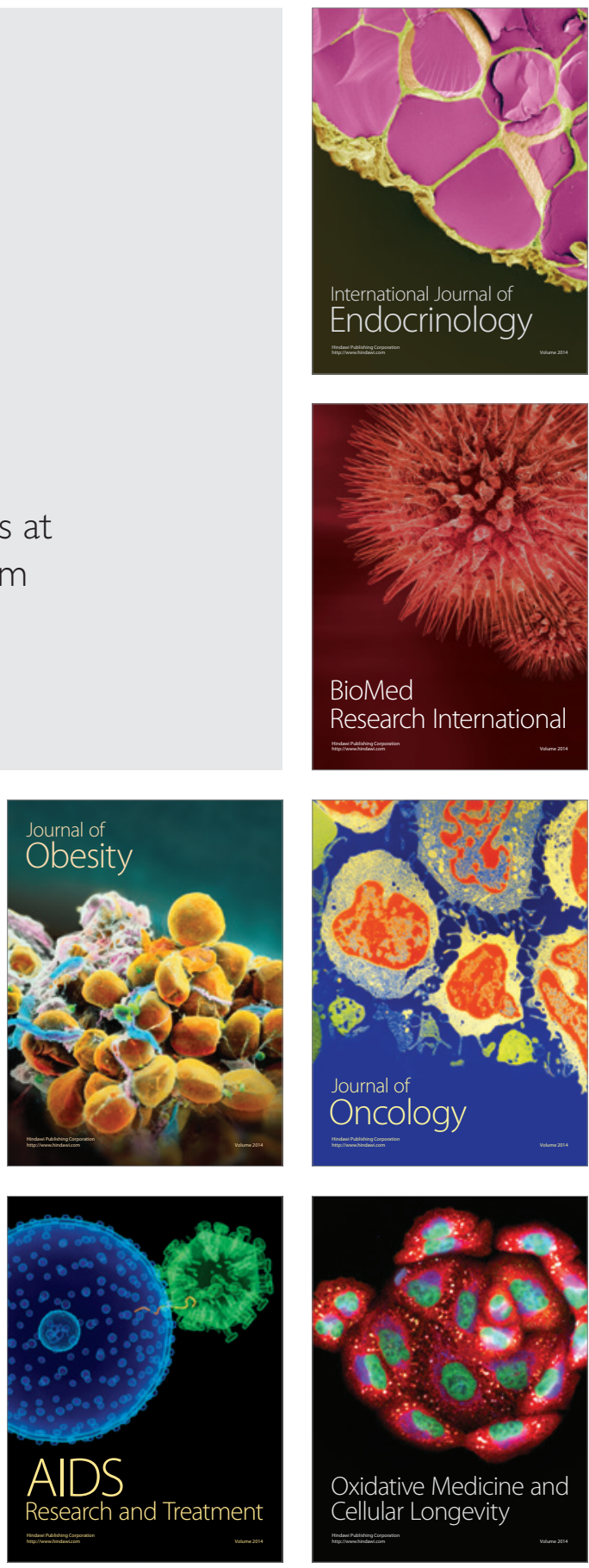